\title{
Over Folliküllerinde ADAMTS 16 Ekspresyonu ve FSH, LH İliş̧kisi
}

\author{
ADAMTS 16 Expression and Correlation with FSH and LH in Ovarian Follicles
}

\author{
Arzu Şahin', Havva Erdem², Mürüvvet Akçay Çelik², \\ Beyhan Mollamehmetoğlü, Ali Aslan ${ }^{4}$, Hilal Balta $^{5}$ \\ ${ }^{1}$ Uşak Üniversitesi, Tip Fakültesi, Fizyoloji Anabilim Dal, Uşak/ Türkiye \\ ${ }^{2}$ Ordu Üniversitesi, Tip Fakültesi, Patoloji Anabilim Dalı, Ordu/ Türkiye \\ ${ }^{3}$ Trabzon Eğitim ve Araştırma Hastanesi, Patoloji Anabilim Dal, Trabzon/ Türkiye \\ ${ }^{4}$ Ordu Üniversitesi, Tip Fakültesi, Fizyoloji Anabilim Dall, Ordu/Türkiye \\ ${ }^{5}$ Erzurum Eğitim ve Araştırma Hastanesi, Patoloji Anabilim Dal, Erzurum/Türkiye \\ Yazışma Adresi / Correspondence: \\ Arzu Şahin \\ Uşak Üniversitesi Tıp Fakültesi, 1 Eylül Kampüsü, Uşak-İzmir Karayolu 8. Km. 64200 Uşak, Türkiye \\ T: +90276221 2121 /6265 E-mail : sahin-97@hotmail.com \\ Geliş Tarihi / Received : 05.05.2020 Kabul Tarihi / Accepted : 02.06.2020 \\ Orcid : \\ Beyhan Mollamehmetoğlu: https://orcid.org/0000-0002-6275-3070 \\ Hilal Balta: https://orcid.org/0000-0003-3745-9694 \\ Ali Aslan: https://orcid.org/0000-0002-9674-5618
}

Arzu Şahin: https://orcid.org/0000-0002-8789-4582

Havva Erdem: https://orcid.org/0000-0002-3074-0240

Mürüvvet Akçay Çelik: https://orcid.org/0000-0002-0335-4045

( Sakarya Tip Dergisi / Sakarya Med J 2020, 10(2):291-298) DOI: 10.31832/smj.732633

Bu çalışma, Trakya Üniversitesi tarafından 2017 Kasım ayında dïzenlenen "1.st International Health Sciences Congress" kongresinde sözlï bildiri olarak sunulmuștur.

Öz

Amaç "A Disintegrin-like and Metalloproteinase with Thrombospondin type-1 motif" (ADAMTS) proteinleri, transmembran glikoproteinlerdir. ADAMTS ailesindeki proteazlarda disregülasyon veya fonksiyonel değișiklikler, polikistik over sendromu ve prematür over yetmezliği gibi üreme bozukluklarıyla ilișkilendirilmiștir. Bu çalışmada; follikül epitelinde ADAMTS-16 ekspresyonunun follikül sitimülan hormon (FSH) ve lüteinleştici hormon (LH) ile ilişkisinin araştırılması amaçlanmıştır.

Gereç ve Çalısmaya 2013-2015 yılları arasında ooferektomi ameliyatı geçirmiş olan ve alınan doku örnekleri patoloji bölümüne gönderilen, 18-55 yaş aralığında toplam 78 vaka dahil

Yöntem edildi. Grup 1; 45 yaş altı ve grup 2; 45-55 yaş arası olmak üzere iki grup oluşturuldu. Retrospektif olan çalışmada vakalara ait parafin bloklardan polilizinli lam üzerine, 3 mikrometre kalınlığında kesitler alındı. Bu kesitlere ABC tekniği ile immunohistokimyasal olarak FSH, LH ve ADAMTS-16 uygulandı. Ișık mikroskobu altında boyanma değerlendirilirken; yok:0, hafif boyanma:1, orta:2, șiddetli:3 olarak derecelendirildi. Doku örneklerinde yapılan patolojik inceleme sonrasında LH, FSH, ADAMTS-16 boyanma sonuçlarının birbirleriyle ve hastaların yaşı ile arasındaki bağımlılık yapısı istatistiksel olarak değerlendirildi. Tüm istatistiksel hesaplamalar SPSS $19.0 \mathrm{~V}$ istatistik paket programında yapılmış olup bulgular sayı (n) ve yüzde (\%) olarak ifade edildi.

Bulgular Hastalardan alınan örneklerdeki patolojik inceleme sonrasında yapılan LH, FSH ve ADAMTS-16 boyanma sonuçlarının hastaların yașına göre değișmediği belirlendi (sırasıyla; $\mathrm{p}=0,215, \mathrm{p}=0,665$ ve $\mathrm{p}=0,508$ ). Ayrıca LH boyanma sonuçlarının; FSH ve ADAMTS- 16 boyanma sonuçlarına bağlı olarak değiștiği belirlendi (sırasıyla $\mathrm{p}$ değeri; $\mathrm{p}<0,001, \mathrm{p}=0,013)$. FSH boyanma sonuçlarının ise ADAMTS- 16 boyanma sonuçlarına göre değişiklik göstermediği tespit edildi $(\mathrm{p}=0,308)$.

Sonuç LH boyanma sonuçlarının; FSH ve ADAMTS-16 boyanma sonuçlarına göre de önemli derecede değiştiği belirlendi. Over fonksiyonlarını değerlendirmede LH, FSH’nın yanı sıra ADAMTS-16 düzeylerinin incelenmesi de önemli katkı sağlayacaktır.

Anahtar Ooferektomi; ADAMTS-16; FSH; LH.

Kelimeler

Abstract

Objective A Disintegrin-like And Metalloproteinase with Thrombospondin type-1 motif (ADAMTS) proteins are transmembrane glycoproteins. Dysregulation or functional changes in the proteases in the ADAM TS family are related to reproductive disorders like polycystic ovarian syndrome and premature ovarian failure.

In this study, an attempt was made to determine the correlation between ADAMTS-16 expression with follicle stimulating hormone (FSH) and luteinizing hormone (LH) in follicular epithelium.

Materials A total of 78 cases, whose age range was 18-55 years, who had undergone oophorectomy operation between 2013-2015 and whose tissue samples were sent to the pathology department were included in the study. Group 1; under 45 and group 2;45-55 years old were formed. This study is a retrospective study. From the paraffin blocks belonging to the cases, 3 micrometer thick
sections were taken on the polilizin slide. FSH, LH and ADAMTS-16 were applied imuunohistochemically to these sections with ABC technique. While the staining is evaluated under light microscope; None: 0 , mild staining: 1, medium: 2, severe: 3.In the study, chi-square analysis was used to examine the dependence structure of LH, FSH, ADAM TS -16 staining results between each other and the age of the patients after the pathological examination on the samples taken from the patients. All statistical calculations are made in SPSS 19.0 V statistical package program and the findings are expressed as number (n) and percent (\%).

Results LH, FSH and ADAMTS -16 staining results after the pathological examination on the samples taken from the patients did not change according to the age of the patients ( $p=0.215$, $p=0.665$ and $p=0.508$, respectively). In addition, LH staining results; It was determined to change depending on FSH staining results and ADAMTS-16 staining results ( $p$ value, $p<0.001, p=0.013$, respectively). FSH staining results did not change according to ADAMTS - 16 staining results ( $p>0.05)$.

Conclusion LH staining results; It was also determined that it changed significantly according to FSH staining results and ADAMTS-16 staining results. In addition to LH, FSH, ADAMTS-16 levels will be important in evaluating ovarian functions.

Keywords Ooferectomy; ADAMTS-16; FSH; LH. 


\section{GIIRIș}

"A Disintegrin-like and Metalloproteinase with Thrombospondin type-1 motif" (ADAMTS) 'ler hem memelilerde hem de omurgasızlarda bulunan bir ekstrasellular proteaz ailesidir. ADAMTS ailesinin üyeleri, A Disintegrin and Metalloproteinase (ADAM) ailesi üyelerinden, çok sayıda kopyası bulunan thrombospondin 1 benzeri tekrarlar ile ayrılır. ADAMTS'ler modular organizasyon, protein sekansı, gen sekansı ve substrat tercihinin korunmuşluğu ile gruplandırılırlar. ADAMTS-1 ilk kez 1997 yılında kaşeksik kolon kanseri modelinde yüksek oranda ifade edilen bir gen olarak gösterilmiştir. ${ }^{1}$

ADAMTS ailesi üyeleri, bir propeptid bölge, bir metaloproteinaz bölgesi, bir disintegrin benzeri alan ve bir trombospondin tip 1 (TS) motifini içeren birkaç farklı protein modülünü paylaşmaktadır. Bu ailenin bireysel üyeleri, C terminali TS motiflerinin sayısından farklıdır ve bazıları eşsiz C-terminal alanlarına sahiptir. ADAMTS ailesi, 19 adet salgılanmış proteinaz içermektedir., ${ }^{2,3}$ Filogenetik olarak, enzim ailesi, bir dereceye kadar görevlendirilen fonksiyonla korelasyon gösteren sekiz kademeye ayrılır4. Diğer metalloproteinazlardan farklı olarak, ADAMTS üyeleri, enzimlerin C-terminal bölgelerinde bulunan, protein tanıma ve matris lokalizasyonunu etkileyen çeşitli eksositler nedeniyle, dar bir substrat özgüllüğünü göstermektedir., ${ }^{5,6,7}$

Bu enzimler, çeşitli dokulardaki hücre dışı matris proteinlerinin düzenlenmesi işlevinde önemli rol oynamaktadırlar. ADAMTS proteazlar agrekan, versikan ve brevikanı parçalama, prokollejenin ve von willebrand faktörün işlenmesinde görev alır. Bağ doku organizasyonu, koagülasyon, inflamasyon, artrit, anjiyogenez ve hücre göçü gibi pek çok önemli role sahip olduğu da gösterilmiştir. ${ }^{1}$ Ayrıca; ADAMTS’ler kadın ve erkek üreme sistemi bozuklukları gibi hastalıklar ile de ilişkilendirilmiş transmembran glikoproteinlerdir. ADAMTS ailesinde yer alan proteinler, hücre membranında bulunan ve çok sayıda bölgeye sahip olan çinko bağımlı metalloproteinazlardır. ${ }^{8,9}$
ADAMTS proteazları ile ilgili son zamanlarda yapılan birçok çalışma da bu ailenin birçok etkilerinin olduğu vurgulanmıştır; özellikle üreme sistemi üzerine olan etkileri oldukça önemlidir. ${ }^{2}$ Üreme organları yetişkin organlar arasında benzersizdir. Çünkü normal işlevlerinin anahtar bir unsuru olarak sürekli doku yenileme sürecinden geçmelidirler. Döllenme, implantasyon, plasentasyon, gebelik ve doğumun yanı sıra kalıcı olgunlaşma ve yeni gametlerin bırakılması süreçleri, doğurganlığı desteklemek için sürekli yenilenmesi gereken dokuların periyodik gelişimi ve regresyonunu içerir. ADAMTS ailesinin, üreme organlarının her birinin gelişimi ve işlevi için gerekli olan doku morfogenezisinin pek çok yönüne katkıda bulunduğu gösterilmiştir. ADAMTS ailesindeki proteazlarda disregülasyon veya fonksiyonel değișiklikler, polikistik over sendromu (PCOS) ve prematür over yetmezliği (POF) gibi üreme bozukluklarıyla ilişkilendirilmiştir. Benzer şekilde, ADAMTS enzimlerinin proteolitik substratları aynı zamanda üreme fonksiyonuyla da ilişkilendirilmiştir. ${ }^{10,11,12}$

İnsan dokusunda yapılan bazı çalışmalarda; ADAMTS16 'nın ilk ekspesyonununu fetal akciğer ve böbrek dokusunda tespit edildiği bildirilmiştir. Daha sonra ki çalışmalarda; ADAMTS-16 mRNA’sının yetişkin beyin ve yumurtalıklarında yüksek oranda ekspresyon gösterdiği ifade edilmiştir., ${ }^{73}$ Yumurtalıklarda ADAMTS-16; ağırlıklı olarak pre-ovulatuar folliküllerin parietal granülosa hücrelerinde eksprese edilir. Gen ekspirasyonu, granülosa hücrelerindeki follikül uyarıcı hormon ve forskolin ile indüklenebilir, bu da cAMP yolunun bu sistemdeki regülasyonunda yer alabileceğini düşündürür. ${ }^{11,14}$

ADAMTS-16 hem böbrekte hem de yumurtalıkta yüksek derecede eksprese edilirken, burada pre-ovulatuar folliküllerin parietal granülosa hücrelerinde ağırlıklı olarak eksprese edildiği bildirilmiştir, ancak kumulus oophorus hücrelerinde hafifçe eksprese edildiği görülmüştür. Ayrıca LH'nın ADAMTS-16'nın ekspresyonunda daha az bir etkiye sahip olduğu tespit edilmiştir. ADAMTS-16, proteazlar için yaygın bir substrat olan alfa-2 makroglobülini (MG) 
parçalayabilir ve bu da foliküler follikül sıvısında yüksek konsantrasyonlarda bulunur. ${ }^{11,14,15}$

Ayrıca ADAMTS-16; ovaryumlarının düzenli ve yeterli fonksiyon göstermesi gibi normal yumurtalık fizyolojisinde önemli rol oynamaktadır. ${ }^{16}$ Bir diğer yandan ADAMTS16’nın invitro çalışmalarda granulosa hücrelerinde hem FSH hem de LH indüksiyonunu artırdığ 1 gösterilmiştir. ${ }^{17}$ ADAMTS proteaslar hem erkek hem de kadın gonadlarının gelişiminde, sperm-yumurta füzyonu ve konseptürün implantasyonunda da önemli etkilere sahiptirler. ${ }^{11,18,19}$

ADAMTS proteazlarının rollerine yeni bir bakış açısı; infertiliteyi gidermeye yardımcı olacak, terapötik hedefler üretmek için klinik potansiyel ile doğurganlığın ardındaki moleküler mekanizmaları daha derinlemesine anlamayı, üreme organlarının işlev bozukluğunu öngören biyolojik belirteçleri geliştirmeyi sağlayacaktır.

Bu çalışmanın amacı; follikül epitelinde ADAMTS-16 ekspresyonunun FSH ve LH düzeyi ile olası ilişkisini araştırmaktır.

\section{GEREÇ ve YÖNTEMLER}

Çalışmaya 2013-2015 yılları arasında Ordu Üniversitesi Eğitim ve Araştırma Hastanesi kadın hastalıkları ve doğum polikliniğine ve Atatürk Üniversitesi Araştırma Hastanesi kadın hastalıkları ve doğum polikliniğine başvurup aldığı tanı sonunda ooferektomi geçirmiş, alınan doku örnekleri de patoloji bölümüne gönderilen vakalar alındı. Retrospektif ve kesitsel araştırma olan bu çalışmada vakaların raporları arşivden çıkarılarak, hastalara ait yaş ve cinsiyet verileri rapor edildi. Çalışmaya; 18-55 yaş aralığında olan toplam 78 vaka dahil edildi. Grup 1; 45 yaş altı $(n=25)$ ve grup 2; 45-55 yaş arası ( $n=53)$ olmak üzere iki grup oluşturuldu. Çalışmaya; diyabet, kalp yetmezliği, kronik böbrek hastalığı ve bilinen kronik kan hastalığı tanısı (trombositik purpura, hemofili, aplastik anemi vb) almış hastalar dahil edilmedi. Çalışma için yasal ve etik izinler Ordu Üniversitesi Tıp Fakültesi Klinik Araştırmalar Etik Kurulu'ndan
02.11.2015 tarihinde ve 2015/7 karar sayısı ile alındı.

\section{Doku Örneklerinin Hazırlanması}

Vakalara ait parafin bloklardan polilizinli lam üzerine, 3 mikrometre kalınlığında kesitler alındı. Kesitler 1 saat 60 ${ }^{\circ} \mathrm{C}$ 'de tutulduktan sonra ksilol ve alkol adımları uygulandı. Kesitler, \%3'lük hidrojen peroksit çözeltisi içinde 10 dakika süreyle inkübe edildi, daha sonra 5 dakika boyunca damıtılmış su içinde yıkandı. Antijen retrival aşaması uygulandı. İmmünohistokimyasal boyama avidin-biotin kompleksi tekniği kullanılarak yapıldı. Daha sonra kesitler üç defa 2 dakika süre ile PBS (fosfat buffer solüsyonu) ile yıkandı. Bu kesitlere ABC tekniği ile imuunohistokimyasal olarak primer antikorlar olan; ADAMTS-16 (Origene laboratories'e ait TA322059 katalog numaralı (1/200 dilüsyonla)), FSH (CellMarque laboratories'e ait 207R-14 katalog numaralı (1/300 dilüsyonla)) ve LH (CellMarque laboratories'e ait 209A-14 katalog numaralı (1/300 dilüsyonla) uygulandi. Kesitler, 3-amino-9-etilkarbazol ve kromojen substrat (10 dakika) içerisinde durulandı. Suyla yıkandı. Hematoksilen (3 dakika) ile boyandı ve sırasıyla balzam ile kapatıldı. Boyanan slaytlar Nikon Eclipse Niu mikroskobu ile incelendi ve fotoğraflar çekildi. İmmunohistokimyasal slaytların derecelendirilmesi semi kantitatif olarak yapıldı. Işık mikroskobu altında boyanma değerlendirilirken; 0 boyanma yok, 1 (\%10'undan az) hafif boyanma, 2 (\%10 ila $\% 50$ 'si arasında) orta şiddette boyanma ve 3 (\%50'sinden fazlası), güçlü boyanma olarak değerlendirildi.16 Değerlendirmede, pozitif boyanma şiddeti stromal hücrelerde ve follikül epitelinde epitel hücrelerinde tespit edildi.

\section{Verilerin İstatistiksel Analizi}

Çalışmada hastalardan alınan örnekler üzerinde yapilan patolojik inceleme sonrasinda yapilan LH, FSH, ADAMTS-16 boyanma sonuçlarının (yok, var) birbirileri ve hasta yaşlarıyla arasındaki bağımlılık yapısını incelemek amacı ile ki-kare analizi kullanıldı. Süreklilik varsayımının sağlanması için her bir hücreye düşen beklenen değer sayısının en az 5 olması gerekir. Herhangi bir hücrede bu sağlanmadığı taktirde bunun düzeltilmesi için iki 
yol vardir.

a) Uygun satırları veya sütunları birleştirme,

b) Yates düzeltilmesini uygulama (2x2'lik tablolarda).

Ancak çok gözlü düzenlerde, Yates düzeltmesi yapılmaz.20 $\mathrm{Bu}$ nedenle çalışmada beklenen değer sayısı < 5 olan satır veya sütünlar diğer satır ve sütunlar ile birleştirilmiştir (Yoğun bir şekilde boyanma görülme durumu orta şiddette boyanma görünme durumuna ait, orta düzey boyanma görülme durumu hafif boyanma görünme durumuna ait bulgular). Tüm istatistiksel hesaplamalar SPSS 19.0 V istatistik paket programında yapılmış olup bulgular sayı (n) ve yüzde (\%) olarak ifade edilmiştir.

\section{BULGULAR}

Çalışmada hastalardan alınan örnekler üzerinde yapilan patolojik inceleme sonrasinda yapilan LH, FSH, ADAMTS-16 boyanma sonuçlarının hastaların yaşına bağlı olarak değişip değişmediği sırası ile Tablo 1, Tablo 2 ve Tablo 3'de verilmiştir. Hastalardan alınan örneklerde patolojik inceleme sonrasinda yapılan $\mathrm{LH}, \mathrm{FSH}$ ve ADAMTS-16 boyanma sonuçlarının hastaların yaşına göre değişmediği belirlenmiştir ( $p$ değerleri sırasıyla; $\mathrm{p}=0,215, \mathrm{p}=0,665, \mathrm{p}=0,508)$.

\begin{tabular}{|c|c|c|c|c|}
\hline \multicolumn{5}{|c|}{$\begin{array}{l}\text { Tablo 1. LH boyanma sonuçlarının hastaların yaşına göre } \\
\text { dağılımı. }\end{array}$} \\
\hline \multirow{2}{*}{\multicolumn{2}{|c|}{ Yaş }} & \multicolumn{2}{|c|}{ Boyanma } & \multirow{3}{*}{$\begin{array}{c}\text { Toplam } \\
22(100,0)\end{array}$} \\
\hline & & \multirow{2}{*}{$\begin{array}{c}\text { Yok } \\
9(40,90)\end{array}$} & \multirow{2}{*}{$\begin{array}{c}\begin{array}{c}\text { Hafif } \\
\text { şiddette }\end{array} \\
13(59,10)\end{array}$} & \\
\hline 45 yaş altı & $\mathrm{n}(\%)$ & & & \\
\hline 45-55 yaş arası & $\mathrm{n}(\%)$ & $30(56,60)$ & $23(43,40)$ & $53(100,0)$ \\
\hline Toplam & $\mathrm{n}(\%)$ & $39(52,00)$ & $36(48,00)$ & $75(100,0)$ \\
\hline \multicolumn{5}{|c|}{$\chi^{2}: 1,534 \quad p=0,215$} \\
\hline \multicolumn{5}{|c|}{ LH: Lüteenleștirici hormon. } \\
\hline
\end{tabular}

Tablo 2. FSH boyanma sonuçlarının hastaların yaşına göre dağılımı.

\begin{tabular}{|c|c|c|c|c|}
\hline \multirow{2}{*}{\multicolumn{2}{|c|}{ Yaş }} & \multicolumn{2}{|c|}{ Boyanma } & \multirow{3}{*}{$\begin{array}{c}\text { Toplam } \\
22(100,0)\end{array}$} \\
\hline & & \multirow{2}{*}{$\begin{array}{c}\text { Yok } \\
10(45,46)\end{array}$} & \multirow{2}{*}{$\begin{array}{c}\begin{array}{c}\text { Hafif } \\
\text { şiddette }\end{array} \\
12(54,54)\end{array}$} & \\
\hline 45 yaş altı & $\mathrm{n}(\%)$ & & & \\
\hline 45-55 yaş arası & $\mathrm{n}(\%)$ & $27(50,94)$ & $26(49,06)$ & $53(100,0)$ \\
\hline Toplam & $\mathrm{n}(\%)$ & $37(49,33)$ & $38(50,67)$ & $75(100,0)$ \\
\hline \multicolumn{5}{|c|}{$\chi^{2}: 0,187 \quad p=0,665$} \\
\hline
\end{tabular}

Tablo 3. ADAMTS - 16 boyanma sonuçlarının hastaların yaşına göre dağılımı.

\begin{tabular}{|l|c|c|c|c|c|}
\hline \multirow{2}{*}{ Yaş } & \multicolumn{2}{|c|}{ Boyanma } & \multirow{2}{*}{ Toplam } \\
\cline { 3 - 5 } \multicolumn{2}{|l|}{} & Yok & $\begin{array}{c}\text { Hafif } \\
\text { şiddette }\end{array}$ & $\begin{array}{c}\text { Orta } \\
\text { Şiddete }\end{array}$ & \\
\hline 45 yaş altı & $\mathrm{n}(\%)$ & $\begin{array}{c}3 \\
(13,04)\end{array}$ & $\begin{array}{c}9 \\
(39,13)\end{array}$ & $\begin{array}{c}11 \\
(47,83)\end{array}$ & $\begin{array}{c}23 \\
(100,0)\end{array}$ \\
\hline $\begin{array}{l}45-55 \text { yaş } \\
\text { arası }\end{array}$ & $\mathrm{n}(\%)$ & $\begin{array}{c}6 \\
(11,32)\end{array}$ & $\begin{array}{c}28 \\
(52,83)\end{array}$ & $\begin{array}{c}19 \\
(35,85)\end{array}$ & $\begin{array}{c}53 \\
(100,0)\end{array}$ \\
\hline Toplam & $\mathrm{n}(\%)$ & $\begin{array}{c}8 \\
(10,67)\end{array}$ & $\begin{array}{c}37 \\
(49,33)\end{array}$ & $\begin{array}{c}30 \\
(40,00)\end{array}$ & $\begin{array}{c}75 \\
(100,0)\end{array}$ \\
\hline$\chi^{2}: 1,299$ & $\mathrm{p}=0,508$ \\
\hline $\begin{array}{l}\text { ADAMTS-16: A Disintegrin-like and Metalloproteinase with } \\
\text { Thrombospondin type-1 motif-16. }\end{array}$ \\
\hline
\end{tabular}

Çalışmada hastalardan alınan örneklerde yapılan patolojik inceleme sonrasında LH boyanma sonuçlarının FSH ve ADAMTS-16 boyanma sonuçlarına bağlı olarak değişip değişmediği sırası ile Tablo 4 ve Tablo 5'de verilmiştir. Hastalardan alınan örnekler üzerinde yapılan patolojik inceleme sonrasında LH boyanma sonuçlarının FSH $(\mathrm{p}<0,001)$ ve ADAMTS-16 boyanma sonuçlarına göre değiştiği belirlenmiştir $(\mathrm{p}=0,013)$.

Çalışmada yapılan FSH boyanma sonuçlarının ADAMTS-16 boyanma sonuçlarına bağlı olarak değişip değişmediği ise Tablo 6'da verilmiştir. FSH boyanma sonuçlarının ADAMTS-16 boyanma sonuçlarına göre değişmediği tespit edilmiştir ( $\mathrm{p}=0,308)$. Ayrıca elde edilen verilerle ilgili boyama sonuçları Resim 1 -3’te gösterilmiştir. 


\begin{tabular}{|c|c|c|c|c|}
\hline \multicolumn{5}{|c|}{$\begin{array}{l}\text { Tablo 4. LH boyanma sonuçlarının FSH boyanma sonuçlarına } \\
\text { göre dağılımı. }\end{array}$} \\
\hline \multirow{2}{*}{\multicolumn{2}{|c|}{ LH Boyanma }} & \multicolumn{2}{|c|}{ FSH Boyanma } & \multirow[b]{2}{*}{ Toplam } \\
\hline & & Yok & $\begin{array}{c}\text { Hafif } \\
\text { şiddette }\end{array}$ & \\
\hline Yok & $\mathrm{n}(\%)$ & $28(71,79)$ & $11(28,21)$ & $39(100,0)$ \\
\hline Hafif şiddette & $\mathrm{n}(\%)$ & $9(25,00)$ & $27(75,00)$ & $36(100,0)$ \\
\hline Toplam & $\mathrm{n}(\%)$ & $37(49,33)$ & $38(50,67)$ & $75(100,0)$ \\
\hline \multicolumn{5}{|c|}{$\chi^{2}: 16,40 \quad p<0,001$} \\
\hline \multicolumn{5}{|c|}{ LH: Lüteenleştirici hormon. FSH: Follikül uyarıcı hormon. } \\
\hline
\end{tabular}

\begin{tabular}{|c|c|c|c|c|c|}
\hline \multicolumn{6}{|c|}{$\begin{array}{l}\text { Tablo 5. LH boyanma sonuçlarının ADAMTS-16 boyanma } \\
\text { sonuçlarına göre dağılımı. }\end{array}$} \\
\hline \multirow{2}{*}{\multicolumn{2}{|c|}{ LH Boyanma }} & \multicolumn{3}{|c|}{ ADAM TS - 16 Boyanma } & \multirow{3}{*}{$\begin{array}{c}\text { Toplam } \\
39 \\
(100,0)\end{array}$} \\
\hline & & \multirow{2}{*}{$\begin{array}{c}\text { Yok } \\
\begin{array}{c}7 \\
(17,95)\end{array}\end{array}$} & \multirow{2}{*}{$\begin{array}{c}\begin{array}{c}\text { Hafif } \\
\text { şiddette }\end{array} \\
22 \\
(56,41)\end{array}$} & \multirow{2}{*}{$\begin{array}{c}\begin{array}{c}\text { Orta } \\
\text { Şiddete }\end{array} \\
10 \\
(25,64)\end{array}$} & \\
\hline Yok & $\mathrm{n}(\%)$ & & & & \\
\hline $\begin{array}{l}\text { Hafif } \\
\text { şiddette }\end{array}$ & $\mathrm{n}(\%)$ & $1(2,78)$ & $\begin{array}{c}15 \\
(41,67)\end{array}$ & $\begin{array}{c}20 \\
(55,55)\end{array}$ & $\begin{array}{c}36 \\
(100,0)\end{array}$ \\
\hline Toplam & $\mathrm{n}(\%)$ & $\begin{array}{c}8 \\
(10,67)\end{array}$ & $\begin{array}{c}37 \\
(49,33)\end{array}$ & $\begin{array}{c}30 \\
(40,00)\end{array}$ & $\begin{array}{c}75 \\
(100,0)\end{array}$ \\
\hline \multicolumn{6}{|c|}{$\chi^{2}: 9,052 \quad p=0,013$} \\
\hline \multicolumn{6}{|c|}{$\begin{array}{l}\text { LH: Lüteenleştirici hormon. ADAMTS-16: A Disintegrin-like and } \\
\text { Metalloproteinase with Thrombos-pondin type-1 motif- } 16 \text {. }\end{array}$} \\
\hline
\end{tabular}

\begin{tabular}{|c|c|c|c|c|c|}
\hline \multicolumn{6}{|c|}{$\begin{array}{l}\text { Tablo 6. FSH boyanma sonuçlarının ADAMTS-16 boyanma } \\
\text { sonuçlarına göre dağılımı. }\end{array}$} \\
\hline \multirow{2}{*}{\multicolumn{2}{|c|}{ FSH Boyanma }} & \multicolumn{3}{|c|}{ ADAM TS -16 Boyanma } & \multirow{3}{*}{$\begin{array}{c}\text { Toplam } \\
37 \\
(100,0)\end{array}$} \\
\hline & & \multirow{2}{*}{$\begin{array}{c}\text { Yok } \\
\begin{array}{c}6 \\
(16,22)\end{array}\end{array}$} & \multirow{2}{*}{$\begin{array}{c}\begin{array}{c}\text { Hafif } \\
\text { şiddette }\end{array} \\
18 \\
(48,60)\end{array}$} & \multirow{2}{*}{$\begin{array}{c}\text { Orta } \\
\text { Şiddete }\end{array}$} & \\
\hline Yok & n (\%) & & & & \\
\hline $\begin{array}{l}\text { Hafif } \\
\text { şiddette }\end{array}$ & n (\%) & $2(5,31)$ & $\begin{array}{c}19 \\
(50,01)\end{array}$ & $\begin{array}{c}17 \\
(44,72)\end{array}$ & $\begin{array}{c}38 \\
(100,0)\end{array}$ \\
\hline Toplam & n (\%) & $\begin{array}{c}8 \\
(10,67) \\
\end{array}$ & $\begin{array}{c}37 \\
(49,33) \\
\end{array}$ & $\begin{array}{c}30 \\
(40,00) \\
\end{array}$ & $\begin{array}{c}75 \\
(100,0)\end{array}$ \\
\hline \multicolumn{6}{|c|}{$\chi^{2}: 2,547 \quad p=0,308$} \\
\hline \multicolumn{6}{|c|}{$\begin{array}{l}\text { FSH: Follikül uyarıcı hormon. ADAMTS-16: A Disintegrin-like } \\
\text { and Metalloproteinase with Thrombospondin type-1 motif- } 16 .\end{array}$} \\
\hline
\end{tabular}

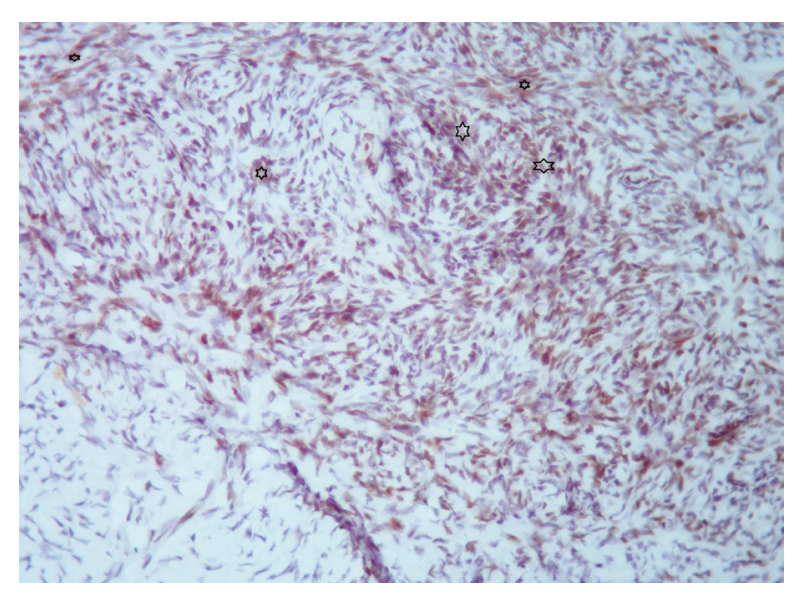

Resim 1. ADAMTS -16 ile stromal hücrelerde sitoplazmik, şiddetli boyanma (yıldız) (x400).

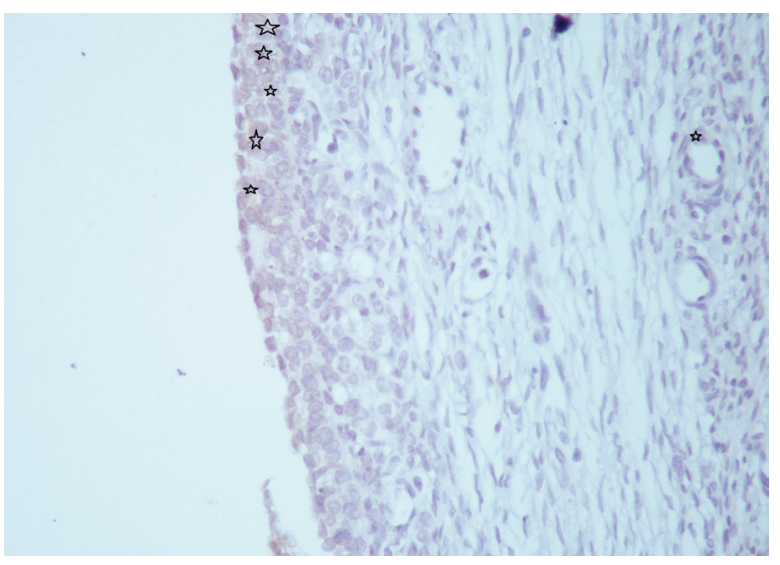

Resim 2. FSH ile follikül epiteli ve over yüzey epitelinde orta derecede, sitoplazmik boyanma (yıldiz) (x400).

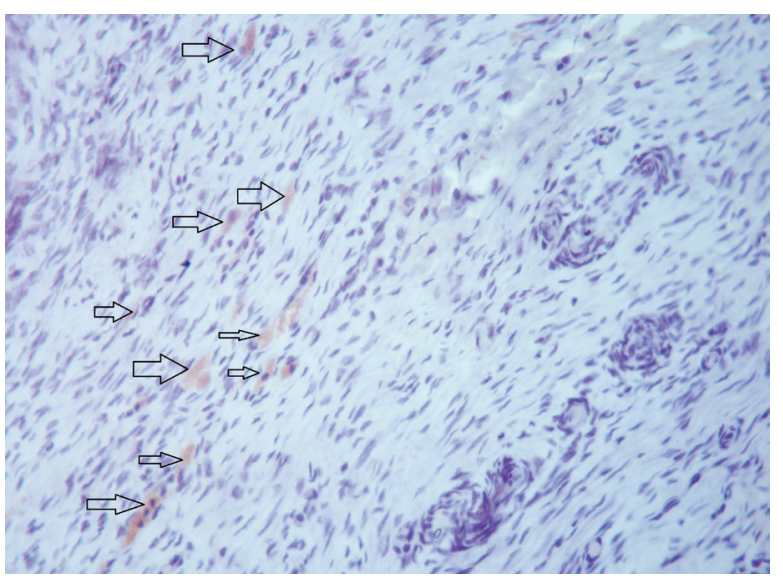

Resim 3. LH ile stromal hücrelerde hafif, sitoplazmik boyan-

ma (oklar) (x400) 


\section{TARTIŞMA}

Follkilogenezis boyunca ADAMTS proteazların birçoğunun salgılandığının görüldüğü ve ovariyal follükül sıv1sında ADAMTS-16 miktarının da önemli ölçüde arttığ 1 bildirilmiştir. Follikül hücrelerinin büyümesinde etkili oldukları, ovulasyonda ve korpus luteum oluşumunda rol aldığı birçok çalışmada bildirilmiştir. ${ }^{15,16,21,22}$

Hipofizden salgılanan FSH hormonu, kadınlarda; ovaryumları uyayarak follikül üretimini artırır, aynı zamanda ovaryumlarda bulunan folliküllerde östrojen hormon salgısını düzenler. Hem FSH, LH, östrojen gibi hormonlar hem de ADAMTS proteazları birçok etken üreme fonksiyonları üzerine önemli etkilere sahiptir. Üreme sistemi üzerine etkili faktörleri ve bu faktörlerin birbiriyle kolerasyonunu inceleyen birçok çalışma yapılmıştır. ${ }^{21,22}$

Yapmış olduğumuz çalışmada; FSH, LH ve ADAMTS-16 düzeylerinin çalışmaya katılan bireyde yaşa bağlı bir değişim göstermediği tespit edildi. Bu durumun çalışma grubunu oluşturan (Grup 1; 45 yaş altı ve grup 2;45-55 yaş arası) gruplarda ki yaş aralığının fazla olmaması ile ilgili olabileceğini düşündürmüştür.

Jung-A Pyun ve arkadaşları 75 kişiden oluşan prematür overiyal yetmezlik hastası üzerinde yapmış oldukları çalışmaları sonucunda; ADAMTS-16 genlerinin polimorfizmlerinde sinerjistik etkileşimlerinin artmış olduğunu ve kadınlarda prematür overiyal yetmezlik sendromlarında miktarının sorgulanması gerektiğini ifade etmişlerdir. ${ }^{23}$ Gao ve arkadaşlarının, overiyal doku üzerinde Real time PCR ile yapmış oldukları çalışmalarında FSH uyarısıyla over follikülerinden yüksek oranda ADAMTS-16 ekspresyonunun olduğunu bildirmişlerdir. ${ }^{11}$ Çalışmamızda hastalardan alınan örnekler üzerinde yapılan patolojik inceleme sonrasında yapılan LH boyanma sonuçlarının FSH boyanma sonuçlarına bağlı olarak değiştiği belirlenmiştir $(\mathrm{p}<0,001)$. LH ekspresyonu; FSH ekspresyonu ile paralellik gösterecek şekilde boyanma göstermektedir ve bu paralellik; FSH ve LH 'in fizyolojik olarak sürekli etkileşim içerisinde olmasının normal bir sonucudur. Ancak Jung ve arkadaşlarının çalışmalarından farklı olarak FSH ekspresyon düzeyinde anlamlı bir farklılık tespit edilmemiştir. ${ }^{23}$ $\mathrm{Bu}$ durumun çalışmamızı oluşturan hastaların yaşlarının çoğunlukla 45 yaş üzeri olmasından kaynaklandığını düşünmekteyiz.

Yapmış olduğumuz çalışmada, hastalardan alınan örnekler üzerinde yapılan patolojik inceleme sonrasında yap1lan LH boyanma sonuçlarının ADAMTS-16 boyanma sonuçlarına göre değiştiği belirlenmiştir $(\mathrm{p}=0,013)$. LH boyama yoğunluğunun artması ile ADAMTS-16 boyama yoğunluğu da artış göstermektedir. LH hormon düzeyinin ADAMTS-16 miktarını ve ekspresyonunu artırdığı bazı çalışmalarda bildirilmiştir. ${ }^{24}$

Yapmış olduğumuz çalışmada kadınların yaş ortalamasının 40' in üzerinde olması ve kadın üreme organlarının fonksiyon bozukluğuna bağlı ilgili kliniğe başvurularının olması sonucunda alınan dokularda yapmış olduğumuz çalışma ADAM TS- 16'nın ekspresyon miktarının over stromal hücrelerde yoğun olduğu tespit edildi. Bizim çalışmamızla paralel olarak Tola ve arkadaşlarının 2017 yılında ADAMTS ailesinden olan ADAMTS-1 düzeylerini PCOS grup ve kontrol gurubunda karşılaştırmışlardır. Çalışmalarında folliküler sıvıda ADAMTS-1 enzim düzeyinin ortalamasinı PCOS grubunda kontrol grubuna göre oldukça yüksek tespit ettiklerini bildirmişlerdir. ${ }^{25}$ Ancak Özler ve arkadaşları 38 polikistik over hastası ve 40 sağlıklı gönüllü de yapmış oldukları çalışmalarının sonucunda da PCOS grubunda serum ADAMTS-1 enzim düzeyinin kontrol grubuna göre istatistiksel olarak daha düşük miktarda olduğunu bildirmişlerdir. ${ }^{26}$

Sonuç olarak, ADAMTS-16 ve diğer ADAMTS ailesi üyelerinin üreme sistemi ve over fonksiyonları üzerine önemli etkisinin olduğu bizim çalışmamızda olduğu gibi birçok bilimsel çalışmada da belirtilmiştir. En sık görülen over fonksiyon bozuklarından biri olan ve kadınlarda infertilite nedenleri arasinda önemli bir yere sahip olan PCOS’un 
etiyopatogenezinde ADAMTS ailesi kısmi bir rol oynayabilir. ADAMTS proteazlarının rollerine yeni bir bakış açısı; infertiliteyi gidermeye yardımcı olacak, terapötik hedefler üretmek için klinik potansiyel ile doğurganlığın ardındaki moleküler mekanizmaları daha derinlemesine anlamayı, üreme organlarının işlev bozukluğunu öngören biyolojik belirteçleri geliştirmeyi sağlayacaktır. Bu konuda daha kapsamlı klinik ve deneysel çalışmalara ihtiyaç vardır.

\section{Etik Kurul Onayı}

Çalışmamız Ordu Üniversitesi Tıp Fakültesi Klinik Araştırmalar Etik Kurulu tarafından onaylanmıştır (Tarih: 02 Mart 2015, Sayı: 2015/7). Ayrıca kadın hastalıkları ve doğum bölümü ile tıbbi patoloji bölümünün kurumsal makamından yazılı izin alındı. Bu çalışma 1964 Helsinki bildirgesi ve daha sonra yapılan değişikliklere veya karşılaştırılabilir etik standartlara uygun şekilde gerçekleştirilmiştir.

\section{Çıkar Çatışması}

Herhangi bir çıkar çatışmasının olmadığı yazarlar tarafından onaylanmıştır.

\section{Finansal Destek}

Bu çalışma Ordu Üniversitesi BAP birimi tarafından AR1510 proje numarası desteklenmiştir. 
Sakarya Tip Dergisi 2020;10(2):291-298

ŞAHIN ve Ark., Over Folliküllerinde ADAMTS 16 Ekspresyonu ve FSH, LH iliş̧kisi

\section{Kaynaklar}

1. Sunay FB, Aydogan Türkoğlu S, Köçkar F. ADAMTS ailesi ve anti-anjiogenetik ADAMTS1. Uludağ Üniversitesi Tip Fakültesi Dergisi 2012;38 (1):49-56.

2. Porter S, Clark IM, Kevorkian L, Edwards DR. The ADAMTS metalloproteinases. Biochem. J. 2005;386: 15-27.

3. Cal S, Obaya AJ, Llamazares M, Garabaya C, Quesada V, Lopez-Otin C. Cloning, expression analysis, and structural characterization of seven novel human ADAMTSs, a family of metalloproteinases with disintegrin and thrombospondin-1 domains. Gene 2002; 283:49-62.

4. Huxley-Jones J, Apte SS, Robertson DL, Boot-Handford RP. The characterisation of six ADAMTS proteases in the basal chordate Ciona intestinalis provides new insights into the vertebrate ADAMTS family. Int. J. Biochem. 2005; 37:1838-1845.

5. Tortorella MD, Malfait F, Barve RA, Shieh HS, Malfait AM. A review of the ADAM TS family, pharmaceutical targets of the future. Curr Pharm Des. 2009;15(20):2359-2374.

6. Rodgers UR, Kevorkian L, Surridge AK, Waters JG, Swingler TE, Culley K, et al. Expression and function of matrix metalloproteinase (MMP)-28. Matrix Biol 2009;28:263-272.

7. Pekcan MK, Sarıkaya E, Tokmak A, Alşsık M, Alkan A, Özakşit G, Erel Ö. ADAMTS-3, -13, -16, and -19 levels in patients with habitual abortion. Kaohsiung J Med Sci 2017;33(1):3035 .

8. Hirohata S, Wang LW, Miyagi M, Yan L, Seldin MF, Keene DR, et al. Punctin, a novel ADAMTS-like molecule, ADAMTSL-1, in extracellular matrix. I Biol Chem. 2002; 277(14):12182-12189.

9. Tang BL, ADAMTS: a novel family of extracellular matrix proteases. Int J Biochem Cell Biol. 2001;33(1):33-44.

10. Russell DL, Brown HM, Dunning KR. ADAMTS proteases in fertility. Matrix Biol 2015; 44(46):54-63.

11. Gao S, De Geyter C, Kossowska K, Zhang H. FSH stimulates the expression of the ADAMTS-16 protease in mature human ovarian follicles. Mol Hum Reprod 2007; 13:465471

12. Espey LL, Yoshioka S, Russell DL, Robker RL, Fujii S, Richards JS, et al. Ovarian expression of a disintegrin and metalloproteinase with thrombospondin motifs during ovulation in the gonadotropin-primed immature rat. Biol Reprod 2000; 62:1090-1095.

13. Wolfsberg TG, Primakoff P, Myles DG, White JM. ADAM, a novel family of membrane proteins containing A Disintegrin And Metalloprotease domain: multipotential functions in cell-cell and cell-matrix interactions. J Cell Biol 1995; 131:275-8.

14. Pyun JA, Kim S, Cha DH, Kwack K. Epistasis between IGF2R and ADAMTS19 polymorphisms associates with premature ovarian failure. Human Rep 2013; 28:3146-54.
15. Kelwick R, Desanlis I, Wheeler GN and Edwards DR. The ADAMTS (A Disintegrin and Metalloproteinase with Thrombospondin motifs) family. Genome Biology 2015; 16:113-130.

16. Richards JS, Hernandez-Gonzalez I, Gonzalez-Robayna I, Teuling E, Lo Y, Boerboom D, Falender AE, Doyle KH, LeBaron RG, Thompson V et al. Regulated expression of ADAMTS family members in follicles and cumulus oocyte complexes: evidence for specific and redundant patterns during ovulation. Biol Reprod 2005; 72:1241-1255.

17. Kikuno R, Nagase T, Nakayama M, Koga H, Okazaki N, Nakajima D, et al. HUGE: a database for human KIAA proteins, a 2004 update integrating HUGEppi and ROUGE. Nucleic Acids Res 2004; 32:502-504.

18. Freimann S, Ben-Ami I, Dantes A, Armon L, Ben Ya'cov-Klein A, Ron-El R, et al. Differential expression of genes coding for EGF-like factors and ADAMTS1 following gonadotropin stimulation in normal and transformed human granulosa cells. Biochem Biophys Res Commun 2005; 333:935- 43 .

19. Russell DL, Doyle KMH, Ochsner SA, Sandy JD, Richards JS. Processing and localization of ADAMTS-1 and proteolytic cleavage of versican during cumulus matrix expansion and ovulation. J Biol Chem 2003;278: 42330-42339.

20. Ress DG, Foundations of Statistics, Chapman and Hall (eds.), 14th ed. New York; 1987;423424.

21. Doyle KM, Russell DL, Sriraman V, Richards JS. Coordinate transcription of the ADAMTS-1 gene by luteinizing hormone and progesterone receptor. Mol Endocrinol 2004; 18:2463-2478.

22. Shindo T, Kurihara H, Kuno K, Yokoyama H, Wada T, Kurihara Y, et al. ADAMTS-1: A metalloproteinase-disintegrin essential for nor $\neg$ mal growth, fertility, and organ morphology and function. J Clin Invest 2000; 105:1345-1352.

23. Jung-A Pyun, Sunshin Kim, Kyubum Kwack. Interaction between thyroglobulin and ADAMTS16 in premature ovarian failure. Clin Exp Reprod Med 2014;41(3):120-124

24. Willis EL, Bridges PJ, Fortune JE. Progesterone receptor and prostaglandins mediate luteinizing hormone-induced changes in messenger RNAs for ADAMTS proteases in theca cells of bovine periovulatory follicles. Mol Reprod Dev 2016; 84(1):55-66.

25. Tola EN, Karatopuk DU, Koroglu N, Ergin M, Oral HB. Follicular ADAMTS-1 and aggre can levels in polycystic ovary syndrome. J Assist Reprod Genet 2017;34(6):811-816.

26. Özler S, Öztaş E, Tokmak A, Ergin M, Kuru Pekcan M, Gümüş Güler B, Yakut Hİ, Yılmaz N. Role of Versican and ADAMTS-1 in Polycystic Ovary Syndrome. J Clin Res Pediatr Endocrinol 2017;9(1):24-30. 